\title{
Law Enforcement in Times of Violent Demonstrations
}

\author{
Syed Kaleem Imam *
}

\begin{abstract}
This paper is an in-depth study on the country's public disorder and the efficacy of police response. In order to understand the dynamics of police response towards violent public order situations, it is important to elaborate complexities of the prevailing environment. The evaluation of this environment revolves around the existing policing practices towards handling volatile law and order situations, available legal framework, and internal challenges to deal with violent situations firmly. The research is based on the police department's shared thoughts, years of handling turbulent situations, and the requisite provisions for an apt response. Besides relevant reports, articles and assessed data have been consulted. Suggestions as to how police can act in a better manner in times, related strategies and tactical procedures have been elucidated.
\end{abstract}

Keywords: Conflict, demonstrations, enforcement, law and Order, Police, protests, response, riots.

\section{Historical Perspective of Conflict and Violence in Pak- istan}

Pakistan came into existence under disheveled terms experiencing deaths of about 1 million people sacrificing lives and properties in the process of independence. Hence, urban conflict is not a novel concept for most residents as it has subsisted since 1947. Still, time and often, the security landscape of the country is entrenched in an array of conflicts and differences of opinions among multiple groups. The proliferation of violence is recognized as one of the deep-rooted and existing phenomena in the country. Political, religious, and ethnic divisions have manipulated violence as democratic and legal instruments to materialize personal goals.

The reason behind the disturbance in the law-and-order situation of the country is primarily multi-dimensional and reflects an in-built, intricate experience stemming from an uncontrollable scenario of socio-cultural multiplicities and its predicaments. Consequently, Pakistan is home to ethnic-linguistic, sectarian, and tribal splits resulting in extensive typologies (Malik, 2009).

With the growth of sectarian and political views, violence is being normalized as a form of protest.

*PhD Scholar, Security Expert, a UN Peacekeeper and is presently serving as Inspector General of Police

NHMP. Email: skimam98@hotmail.com 


\title{
Criminal Justice System
}

The three main components of the criminal justice system are Police, Courts, and Corrections. Masses are the principal clientele and prosecution work as an independent department. Each branch is interlinked in terms of causes and implications and is considered the backbone for law-and-order maintenance.

\section{Law enforcement in Pakistan}

Law enforcement in Pakistan is conducted through the alliance of federal and provincial police organizations along with other enforcement authorities. These agencies are primarily vested in providing a safety umbrella to the public, secure infrastructure, maintain law and order throughout the country.

\section{Analysis of Police Capacity towards Public Order Situ- ations}

Astoundingly Pakistan has encountered a vivid history of protests, demonstrations, and mob organization, but no explicit and well-defined training has been given to the forces. Even if there are few drills imparted, the practicality of concepts and actions is more required at a ground level for the desired results. Unfortunately, sudden eruption in violence due to various occurrences including mass movements, arsons, and lootings had become the norm. Police is confronting this situation since the early 50's, but regrettably, serious attention has not been paid towards capacity building of the police department to handle such conflicts and hostilities to counter-protest (Hameed, 2013).

It is time that police must be alerted about the sensitivity for proper handling of sectarian and religiously driven masses. The analysis of the latest protest divulges interesting findings of the group involved and the approach adopted.

\section{Handling of TLP Protest; A Critical Study of Police Response}

\author{
"Law and order is the responsibility of the state government." - (Mamata \\ Banerjee)
}

\section{Historical Perspective}

Pakistan has witnessed a myriad of political, ethnic, religious conflicts and riots for a long time. Generally, certain activists make sit-ins, some make roadblocks and others shutter down prolonging the protests whereas religious groups forcefully demonstrate their emphasized beliefs. In past, the protests were generally unruly to the extent of throwing stones and bricks at police. Deadly weapons were rarely used and effective supervision 
by stakeholders simplified the route of rallies. Mutual consent was observed, enabling predictable contingency through security plans.

However, the nature and dynamics of protests lodged by religious parties have also undergone a radical shift over the last few years. The routinely predictable protests now turn violent and proper handling is considered vital to ensure public order. A recent addition to this phenomenon is Tehreek-e-Labaik Pakistan (TLP). It has emerged from the sectarian divide in the country and has carried out numerous violent demonstrations. However, the most pertinent is the recent TLP protest that made rounds when it launched a nationwide strike and contest against the authorities and maneuvered for their objectives.

\section{Background of TLP Protest}

The principal aim behind extremist demonstrations was France's interpretation and expression on freedom of speech and Islam. It was considered highly blasphemous within the Muslim community. The primary objective for protests was linked to the murder of Samuel Paty, a French middle school teacher, becoming the highlight of media scrutiny and following noteworthy events. Supporters of TLP gathered and created widespread upheaval in the metropolitan cities that included physical and violent clashes. The TLP generated large-scale protests and strikes which started on the 11th and continued till 20 April 2021. TLP insisted on the sacking of the French emissary as a result of images and cartoons published in France. The demonstrators argued for an embargo of French trade-in, and other French associations. The protests became hostile throughout Pakistan after the party's front-runner Saad Hussain Rizvi was arrested on 12th April 2021 (Hashim, 2021).

Earlier, it all began when Saad Rizvi provoked his followers through a video message asking the activists to unveil series of demonstrations throughout the country if the government failed to expel the French ambassador from the country as per some apparent promise. On 12th April, Rizvi was detained in Lahore and indicted under Pakistan's AntiTerrorism Act, 1997 (ATA) for provoking protesters, triggering turbulence and massive disturbances adversely affecting the infrastructure, economic activities, business events, and transport routes.

\section{Consequences of Protest}

The wrangle between the authorities and religious groups resulted in large-scale clashes, destruction of personal and public possessions along with loss of precious lives. Social, economic, commercial, and tourist activities were affected, with property and business loss to the tune of billions. The profanity could not be tackled diplomatically due to the adamancy of protestors to overwhelm the administration. The second Ameer of TLP Saad Rizvi was later detained in Maintenance of Public Order. Hundreds were arrested in the cases registered later on. The repercussions of these demonstrations were severe. The protesters martyred four front-liners from Punjab Police. The local police with the support of the paramilitary forces contained the situation. In the entire conflict, TLP also lost a few of its protestors. 


\section{Action against TLP}

Subsequently, TLP was proposed for the ban list authorized by the Pakistani government on 15th April, condemning them of terrorism as their protestors were seen terrorizing through street violence and attacking law enforcers. However, the ban on TLP was not realized as it unequivocally required an order from the Pakistani Supreme Court. The administration briefly barred social media for hours to curb the protests, as the TLP held broad social media penetration.

Later, the administration blocked coverage of the protests on local media. On 18th April, 11 policemen taken hostage by TLP were released, and agitation came to an end. The government had subsequently banned the TLP following the violent protests and sitins across the country. The Punjab government had since kept Saad Rizvi in detention under Section 3 of the Maintenance of Public Order Ordinance 1960. After the detainment of Saad Rizvi on 12th April, TLP filed for a petition for the release of their leader. The Supreme Court of Pakistan is prepared to hear their plea on 12th July on accounts of inciting the public and TLP followers to defy the law (Bilal, 2021).

\section{Assessment of Police Response}

In the said protests, police had responded in mixed manner initially. The overnight arrest of the TLP leader in the background that he had announced to march to Islamabad created commotion and allowed other tiers of TLP leadership to take their ideas to the street. Caught in between the protestor agitation, the government will, and leadership stance, placed the force on the left foot. Thousands of police officials were at the outset severely pounded with serious injuries. Subsequently, police responded with heavy hands and controlled the situation. In the process, four officers got martyred. Hundreds of police officers were wounded. In the end, dozens of TLP protestors were arrested. The major scuffle took place at the last blockade near the TLP madrasah where two TLP agitators succumbed to injuries. Things finally settled down, as the management used sizeable force, disbursed the crowd as well as negotiated with TLP and its supporters (Tanzeem, 2021).

Identification of weak areas is an essential starting point for any prescription for mob/riot control. The recent TLP brutalization of police personnel resulted due to individual officers getting caught by the mob. This was because anti-riot police failed to act as a unified strength rather than individuals pushing through incoherently. "Violent protests by the now-banned Tehreek-i-Labbaik Pakistan once again put the police in the direct line of attack, resulting in hundreds of casualties in the service. Police complain that their concerns fall on deaf ears, while they are often castigated for their brutality" (Waseem, 2021).

This gives rise to further debates on the efficiency and credibility of the department. However, it is often said that the police casualties aided the authority ride on the sympathy wave and took the firm decisions that ultimately helped castrate the perpetrators to the sentence. The police chief's policy, of not allowing the use of firearms by the police was a pragmatic decision; or else, the sympathy wave would have turned contrarily, and the police would have lost high moral ground. 


\section{Lessons Learnt and Suggestions for Improvement}

Law and order can be an issue in any society. As any riots become rampant in a society, the police department should build its capacity to professionally respond to diffuse situations, save lives, and avoid collateral damage besides safeguarding its constabulary. Dealing with a motivated and religious crowd can be a real challenge. State relationship with homegrown militant groups since the 1980s has undergone various phases.

Sporadically, mismanaging demonstrations is a fusion of poor intelligence, lack of will, ability and poor assessment of crowd intent. Besides leadership timidity, political leanings, ground management, not properly geared up and coherently retorting gives undesirable results. There is no doubt that the police successfully handle numerous protests and rallies on a daily basis, however, at times, either due to capacity issues, political expediency, or leadership/force glitches, law enforcement agencies are slammed and are held liable for their doings.

Transforming the current police service to a well-functioning department cannot happen in isolation. All stakeholders including the executives, legislatives and judiciary are required to be on board. But it is time that the legislated Police Reforms should be carried out in letter and spirit without any expediency. The lessons learned from handling the TLP protest have once again reminded the authorities to identify the weak areas in the Riot Control Mechanism of Police. Its improvement depends on professional, legal, and tactical reforms.

\section{Deficiencies in the Existing Mechanism}

\section{Trust Gap}

Unfortunately, the policing department of Pakistan has experienced a lack of credibility, trust, and reliability among the public. There is a gap between police and the community leading to confidence issues. Ordinarily, citizens avoid going to the police as they believe interaction will further advance their grievances instead of any redressal.

Pakistan law enforcement should take on trust-building strategies that entail "problem recognition", "generation of strategies", and "adoption of strategies". The police are functioning in a dynamic and institutional environment therefore trust cannot be studied in isolation. Trust leads to legitimacy and no authority can flourish without legitimacy therefore police organizations should be recognized as a legitimate platform that needs to be trusted by the people and other departments as well (Schaap, 2021). However interestingly, despite all negative perceptions, police in Pakistan is still considered a panacea and is expected to solve the emerging crisis and manage all issues. Thus, police is the actual first line of defense during demonstrations, and so comes into the limelight and their act curtail some adversity.

\section{Strategy cum capacity issues}

Successful policing actions are different in terms of theoretical perspectives. In the practical realm, the effectiveness of the strategy is directly linked to practical employment and 
the efficacy of outcomes. Police should be analytically skilled and professionally strong to formulate a practical approach. In order to have rewarding results, there should be a similar trajectory and connection between theoretical and practical approaches for positive and desired output. However, the police is mostly prepped with theoretical knowledge and insights as to how to contain violent protests and political riots, but when it comes to the actual implementation, there is a lack of "will, support, strategy, tactics, and absence of authorization" (Abbas H. , Reforming Pakistan's Police and Law Enforcement Infrastructure, 2011).

\section{Tactical actions anomaly}

The planned level actions are slow. For instance, the supervisors tell their force that the official transport will be provided. Still, many had to use their transport to reach the spot, oddly parking their vehicles near the activists. On withdrawal, the first motorcycles that get burnt are generally of police. Police officials get tired due to endless hours and days of duty without any action, at times begin buying the protestor's narrative. They are usually multi-tasked, with prolonged duty hours making them aggressive. Consequently, when the force is needed in action, they go in halfheartedly due to tiredness or change of their assertion (Siddiqi, Butt, \& Afzaal, 2014). The transporting equipment and carrying riot gears otherwise slow down the men, getting sluggish they end up in the hands of the protestors.

\section{No clear directions}

There are usually unclear directions from the authorities regarding what kind of measures are to be adopted in the distinct varying settings. For instance, there are general instructions that men should not have weapons and only anti-riot equipment is to be carried and used. When the situation turns violent, anti-riot equipment efficacy erodes and fails to disperse or even protect the law enforcers and nearby property. Additionally, police leadership should be well acquainted with theories and the applications leading to team coordination in violent as well as passive situations. Clear directives should not only be provided through standardized management but also "tailored" to meet subjective perspectives (Haberfeld, 2006).

\section{Aspects of ambiguity}

Many times police force is not sure about the legality of the use of force and is fearful of consequences short of clear political resolve. There had been a history of victimization, which creates added confusion. Plus, there is no operational and tactical dissection of past major events, no after-action review by researchers and development experts to guide for future course of action. Earlier incidents are not referred for any studies by policymakers and implementers. Success stories are applauded on electronic and social media, while errors end up in the corridors of judicial inquiry.

Not learning from the past leads to more failures. If preceding events are analyzed and assessed, policy experts can launch anti-riot narratives, creation of elite forces, and 
derivatives from successful policy models to prevent and counter future events (Abbas H. , Role of Pakistan Police in Counterinsurgency).

\section{Lack of Mob Handling simulation exercises}

Unfortunately, protest at times is seen as an opportunity to test procedures or exhaust expired stored anti-riot equipment, including tear gas shells. Gadgets must otherwise be service-worthy. If multi-agency cooperation is a permanent feature for the mob-handling, cooperation should be demonstrated frequently rather than on the riot day. Mob handling simulation exercises are equally crucial for supervisory ranks. It has been observed that despite training, action by the police for the mob control force is quite different, and they practically respond to such situations ineptly. Briefing by senior officers appears to be missing, and there is no clarity regarding the limits of use of force and rules of engagement.

\section{Inconducive working environment}

Other than evident predicaments, police cadres require public confidence to execute and implement duties as a community force. This is displayed through working ambiance, living conditions, and prolonged working hours with multitasking (Siddiqi et al., 2014). They are provided with insufficient benefits and facilities, exhausting their physical capabilities disabling them to perform effectively when required.

\section{Lack of professionalism}

The casual attitude of officials on crowd duties may end up being taken hostage or beaten by the mob amidst protest. It has been observed that constabularies become sympathizers of the protestors. They steer agitators on police plans and tactics to overcome strategy. Police tactics of mob handling are frequently leaked to the media. Eventually, the protesters know about what the police intended to do. All anti-riots training should be based on ground realities. Mainly due to a lack of anti-riot equipment, police officers resort to the use of firearms which should not be encouraged. Failure to resort to a professional attitude results in unproductive and inapt responses hampering the administration's role to curb disorder which is their foremost priority (Ahsen, 2018).

\section{Lack of Skilled Training}

Police deployment focus is still limited on figures of rioters instead of skillful handling of the mob. Additional force is usually sent from the reserve of police stations without any commitment or responsibility towards the law-and-order situation. There is no segregation of personnel according to age group. Consequently, police witness multiple injuries among police personnel from different age groups. Aged policeman is more likely to be made hostage in the hands of the mob. Operational tactics and maneuvering are of textbook mode. This handicaps them, and they are unable to respond to the ever-changing movements and situations of the mob. 
Deployment and training appears to be disorderly. Police should introduce advanced and sophisticated recruitment and training practices for swift and systematic action for minimum collateral loss (Abbas, 2012).

\section{Communication gap}

Unfortunately, law enforcement agencies' suggestions and assertions fall on deaf ears of charged protesters. There exists a lingering barrier in terms of the communication channel between the two on road. The protesters are fueled with passion and infuriation, so, the police bear significant damages in terms of equipment loss and at times of lives on the first encounter. Communication in all sense is derived from "blaming, directing, persuading and problem-solving." Effective community policing and riot containment can only be achieved if police officers are trained in "persuasion" and "problem-solving" aspects. Blaming techniques applied during riot situations would further aggravate rather than control it. Therefore, the force should be aware of de-escalating the protests by removing hostile tones and attitudes that may further incite the protestors.

The police go through extreme challenges because of the alienated sentiments and public outlook as they dwell in uncertainty. If excessive force is applied, then the concern of legitimacy is highlighted whereas lack of force by the police officers gets them admonished.

"You can't say there is only one way of doing things, the police way of ensuring law and order." (Mani Ratnam)

\section{Requisite Intervention by Police Leadership}

\section{Re-evaluation by Command}

Leadership should reassess the weak areas of police response perceived in recent riots. Detailed action as per policy rules needs to be studied and updated as per recent experience. A different methodology should be adopted to tackle religiously motivated, unruly, and charged crowds compared to politically planned agitation. Deploying old and unfit personnel to fill the strength is counterproductive. There should also be a woman contingent to handle ladies' sit-ins.

Even well-trained and well-equipped police cannot succeed unless they have legal and constitutional protection to deal with the illegal assemblies of mobs. If only the culprits are properly trialed and convicted, one would not see such defiance of the law (Minhas \& Shah, 2019). Keeping all other factors constant, appropriate and sufficient strength is the key in successfully handling any agitation; this was obvious during the current handling of law and order in Punjab. In some districts, police initially did operations with insufficient strengths and could not succeed. Later, after mustering more strength police cleared the same agitation quite comfortably.

The local police with the full support of the Special Branch (SB) and Intelligence Bureau (IB) must remain aware and well ahead of the Modus Operandi of these miscreant elements. To interlink the working of SB and other branches of the police, a command center was also launched at Special Branch Headquarters in 2011, responsible to inspect law 
and order situations, sectarian violence, riots, and security situation (Institute for Social Policy and Understanding, 2009). Police must also initiate all the necessary, preventive, and all post-Operation Legal Actions, to defeat miscreants' plans and unlawful operations. Public order handling should be taught to supervisory officers in National Police Academy (NPA) and Police Colleges to understand Police Practical Working (PPW) for better crime control.

All Provincial Special Branches should comprehensively prepare reports against proscribed organizations registered as political parties. Such reports would be helpful for the government before the Election Commission of Pakistan (ECP) and Supreme Court (SC).

\section{Internal Control and Executive Strategies}

Anti-riot police should be organized in sections of individuals with one upper subordinate as in charge and they must remain together, regardless of the situation, under any lawand-order state of affairs. Performance should be in groups to enable the highest level of esprit de corps and support for each other when caught in an adverse situation.

Specialized Anti-Riot Force (ARF) at each district level should not be deployed other than law and order situation. One unit of ARF should always be available with Range DIG for reinforcement if the need arises. Approving special allowance and expanding the ARF will help the policemen to deal with the agitators in times of protest and increase their capability. All districts should maintain units of rapid response force for spontaneous protests (Anti-Riot Force to be Expanded, 2020). The Rapid Response Force should assess the situation and engage the crowd if it is small enough to be safely managed by them. First responders Rapid Response Force (RRF) should pass on their assessment to Police Control and backup force should be sent from the District Anti-Riot Force in the shortest possible time. RRF should secure the area and divert traffic. Every province has a wellarmed and effective Constabulary that should be used as a backup force in case of armed resistance by violent protesters. However, care must be taken not to use the Elite Police in riot situations.

\section{Overhauling Training}

The reconsideration and amendment of the old curricula and supplanting it with the upgraded version will establish methodology and content streamlining. Emphasis on physical training will shift paradigms towards behavioral improvement and acquisition of professionalism. Shifting organizational structure, fostering community response, gender response, police and human rights compliant policing will help assist the policemen in terms of training(Minhas \& Shah, 2019). Periodic drills of tactics to deal with sit-ins, roadblocks, unruly mobs, and strike calls at HQs are a must. The SDPO must supervise the weekly rehearsal of protest handling in each PS.

There should be a specialized training school for anti-riot staff at the provincial level, and the Police Lines Training Schools should be active all the time (Abbas, 2012). Make rules of engagement (ROEs) into standard operating procedures (SOPs), drill, and rehearse. Human rights and the application of force must be part of the training module for ARF. 
Personality development and grooming of police officers will allow a smooth transition from violent management of the mob to a diplomatic way to settle the inconsistencies.

\section{Skill Attainment}

Anti-riot and mob control is a highly specialized job. It calls for highly trained, well equipped with clear rules of engagement. Throughout the world, law enforcement and anti-riot job are done by the specialized units of the police. After the unfortunate riots at the Minhajul Quran Secretariat in June 2014, the capital city police Lahore launched anti-riot units of a few hundred constables trained for large-scale demonstrations (Lahore Gets Anti-Riot Police Force, 2017). Initiated at Qila Gujjar Singh Police Lines and in collaboration with Pakistan Army and Elite Police, the anti-riot modules included insights about shields, megaphones, fire rubber bullets, and the use of batons when required, along with first aid services to injured protestors. To lessen the damage and achieve desired results, field police officers, including station house officers to divisional SP's should have the necessary independent authority, mutual synchronization, planning, and strategizing skills to timely respond in any eventuality.

Since police is a complex and highly structured department, it requires in-depth training and skill attainment inculcating multiple divisions of hierarchy. The police department should be transfigured in terms of conventional skill attainment to a comprehensive instructive level with a specialized form of training. For unanticipated scenarios, such as mob/riot control, vertical and horizontal variations and propagation is necessitated to reform police responsibilities (Fasihuddin, 2012).

\section{Rapport among tiers}

There should be an inclusive and trustworthy relationship between the officers and men. It is promising that at many places, officers now lead from the front and stay with their constabulary. This relationship needs to be robust for the ensuing days as well as in times of normalcy (Perito \& Parvez, 2013). Officers must spend more time with their men otherwise as well, on a regular basis and should develop a relationship. In such an environment, the likelihood of force standing behind their officer in charge and not abandoning in crisis is unequivocal.

\section{Peripheral influence}

The assurance of police modernization and the promise of police being made an apolitical entity is crucial. Having biased and patronized police serves no purpose and dilutes professional credulity. Handling crowd becomes very difficult as a lack of transparency and fairness further incites the violence. Improving policing and humanizing the institution is highly necessary to overcome the impending conundrum as it helps in managing and encountering violent situations.

Extraneous interference and the constant interaction of third-party businesses in the police institution are not productive. Law enforcement authorities get distracted and disturbed if there is constant third-party intervention by the different parties (Kahlon, 2020). 
For police to act efficiently, all aspects of the organization should be acutely examined, and a suitable way forward should be provided. The predicaments faced by the police community should be instantly addressed so that the police performance in rallies like TLP protests or any other upcoming strike can be handled in a better manner.

\section{Skill enhancement at Tactical Level}

"Blessed are the Peace Makers (Matthew)"

\section{Macro Tactics}

\section{Preemptive Approaches}

Preventive detentions are a far better strategy than a confrontation against a proscribed militant organization. Detaining Saad Rizvi of TLP before they could converge at Faizabad, however, was a pragmatic tactical move. A policy of restraint and minimum use of force is far better than indiscriminate and violent use of force by police. An intelligence-based proactive strategy is needed to foil the designs of militant organizations that want to create chaos. Placing their activists and office-bearers in Schedule-IV of ATA and going for preventive detentions will put all such groups on the defensive.

\section{Application of Equipment}

Capabilities of law enforcement have been transformed as police is drastically including technology in their roles and responsibilities. They make use of tools and apparatuses to analyze the potential unruly incidents and identify preemptive stances of violence and riots. With the utilization of digital cameras, artificial intelligence and closed-circuit video cameras, police can identify active propagators of riots and detain them for containment (Manes, 2019).

Novel gadgets and state-of-the-art concepts help in identifying culprits within the protesting lot and give out transparency for ideal results therefore technology can be considered as a great help to identify people in the mob. International Mobilizer Subscriber Identity (IMSI) catchers are available in the market. National Radio and Telecommunication Corporation (NRTC) also makes IMSI catchers and can record all active Subscriber Identification Module (SIM)/ IMSIs in a particular area. These can be used to identify mobile/ cell phone users present in any area at any time. These can be later used to identify and arrest supporters of vandalism.

Furthermore, the deployment of new methodologies such as big data, cell phones, crowdsourcing, blogging, social media platforms, and crisis mapping can help the authorities figure out a tactical way to handle the sit-ins and demonstrations with the potential to escalate. Big data trends are utilized by developed societies to track and understand the trend of events however, it is unfair to completely depend on big data for conflict prevention (Mancini et al., 2013). 


\section{Role of Private Sector in Violence/Riot Containment}

For competent policing, the enhancement and strengthening of the civil society and the private sector is equally necessary to foster a productive environment. The private sector is known to design, formulate, implement, and practice interventions for marginal voices to be heard and influence legislation directly and indirectly for the police to perform in its maximum capability (Bhattacharya, 2016).

"Civil Societies regulate the collective life at the intermediate level and act as mobilisers of people's opinions and actions" (Qadeer, 1997). A strong democratic society with peaceful demonstrations has a robust civil society. These organizations act as intermediaries between the state and common people to achieve democratic standards, maintain rule of law and intact communities.

\section{Micro tactics}

\section{Equipment Utilization}

Despite being given the equipment, some policemen try to avoid wearing the anti-riot gear. When not wearing a helmet/ jacket, they flee at the sight of the first incoming stone or stick. Protective gear when worn gives confidence and strength, which is not witnessed due to noncompliance, a failure at the supervisory level. Upper subordinates should be responsible for ensuring the use of gear. Commanders should lead by example by themselves wearing full anti-riot gear. The tendency of not wearing gear is significantly higher in make-shift platoons from police stations.

Mobs thrive on the outcome of the first onslaught. If the police forward line can withstand the first thrust by the mob, there are chances that police will push them back, making them run for their safety. During riot containment, the front-line officers should be in an armory and fully equipped with batons specially featured for direct action with the crowd. To ensure that the police forward line can withstand the first push, the presence of the commander is of crucial value. This emphasizes the importance of physical gear as well as tactical commandership as an anti-riot approach. Maintaining formations and proper use of shields is essential as well. The greater our understanding with troops, the higher is the probability of their putting up a good stand up.

\section{Buddy System}

Mob handling is a team effort where no individual heroics work is required. Apart from formations, there must be a buddy or group system. Every individual must know that someone is watching his back. This buddy system binds the men together, giving them courage and morale. For men in anti-riot force, the certainty of serving for a tenure helps.

In riot handling, centralization is not going to make police capable of responding to the situations effectively. For example, the anti-riot force unit stationed at Lahore cannot move to any far-flung district well in time, except if there is an air source available, as, during such a situation, roads get blocked. Therefore, every district unit under the District Police Officer (DPO) command should have its capable anti-riot unit with equipment. 
Effective measures must be taken in case of their absurdity. Police should have legal protection for their just actions as they fall prey eventually for political expediency in case of collateral damage. As per the spirit of Criminal Procedure Code (CRPC), police officials cannot be criminally charged for what he does in the discharge of his duties in good faith.

\section{Negotiations}

"Crime is naught but misdirected energy." Emma Goldman (1869-1940)

Priorities should be given to negotiations and talks to minimize the use of force. For this purpose, influential, locals and elders of the area should be incorporated for negotiations or mediators. Direct talks by accredited police officers also help. Police should develop public-friendly behavior to build a better image for successful negotiations.

Cooperation can be achieved if tactical police officers and commanders are prepared to go all-in and resolve conflict or riot situations through diplomacy. A negotiated settlement can significantly reduce the chances of large-scale demonstrations or protests causing further disturbances. Police officers should acknowledge the demands of the protestors, establish contact but at a distance, resolve friction and volatile deadlocks leading to significant losses of life (Wind).

\section{Clear-cut Orders}

The order should be lawful, clear, well pronounced, and it should be in writing. If any error happens in the heat of battle, the commander should be brave enough to own them. The orders should be followed within a legal framework. Training and resources can only produce results if there is clarity in directions to officers on the ground.

\section{Assessing Crowd Temper}

For successful mob handling, ascertaining the temper of the mob is critical, inform the police control, establish classification, i.e., whether it is political, religious, aggrieved, students, labor, civil society, social walks, rallies, etc.

\section{Amenities During Act}

Police units should be provided with the best protection gears against anti-riot strategies like water cannons, APCs, tear gas, rubber bullets, and drones, etc., to enhance their capabilities. Every district should have sufficient anti-riot equipment with earmarked force. Proper anti-riot gears/ gadgets must be available in each police stations (PS).

\section{Ensure and avoid}

"Cops Works for a Cause Not an Applause" (Matthews).

It is not encouraged to exchange insults or beat the crowd. If firearms are to be used, identify the targets and not fire indiscriminately. Police should be able to restrict force 
and firearms in compliance with international standards. The use of firearms should be deployed if there is an impending threat of death to curtail the risk (The Law on Police Use of Force Worldwide, 2021). Arrest and transport teams must be separate that can move in and out of the scene. Train the police officers about escalation and de-escalation of the situation, do not use force on arrested participants, and show no anguish on the spot as this usually gets captured on camera and this is to be avoided by local commanders. Members of Anti-Riot Police be made to work in groups and never go solo in hot pursuit against miscreants lest they become victims of mob violence. Avoid using force when the police contingent is weak in strength; generally, minimum force be used as most of the protesters are innocent beside males should not handle females.

Force in plain clothes should not use force or carry weapons, intelligence, and information gathering must be efficient, deploy in extensive formations, and do utmost care while using force against the mob. Keep all options of force available, the proportional use of force (according to the resistance put up by the mob), guard sensitive points which may fall in the way of dispersing crowd. Injured protesters must be given first aid by police ambulance available on the spot or be evacuated to the nearest hospital by the police and arrest of the mob leaders to be done if the protest goes violent.

All temporary protests carried for genuine reasons must be dealt with empathy, arrest/detain the local leaders when information about a violent protest is received and use a public address system. Remember, anti-riot police are not supposed to follow the crowds for arrest; they must know exactly their role, which is to keep roads clear, contain the rioters and restrict their activities. All activity must be reported to the nearest control for any help or further support, dedicated video recording be done for effective prosecution later, and finally, retreat should be systematic.

\section{Strategic Moves}

Efficient strategies should be developed to isolate the leaders from the crowd and individuals who are not in groups be arrested. Disrupting the communication system and crowd attention be distracted. Do not let the crowd gather in considerable number by controlling the means of transport.

\section{Various Formations to Tackle Situations}

Column formation, contest line (contain the crowd), force formation (penetrate and divide the crowd) be set up. Additions to be made in the formations of the following separate teams: Tear gas, Water cannon, Rubber bullets, Firearm team, deploys ambulances along with anti-riot formations.

\section{Long Term Measures}

The police force that assists the citizens ultimately restores public confidence and helps in stabilizing the democratic transition. Following programs at the administrative levels should be implemented to reform the police for potential threat assessment. 


\section{Instilling Confidence}

The police force shall be effective only when they know that their leaders are behind them. Inaction or indecisiveness demoralizes force. Their morale should be uplifted by reducing corruption, increasing funds and facilities. Further, family protection against harm should be guaranteed to the families of personnel. In the case of police officers who have been martyred in the line of force, pensions should be provided and their acts of valor should be publicly lauded (Reforming Pakistan's Police, 2008). Moreover, in unfavorable situations, mainly due to political exigencies, the sacrifices of men should be acknowledged. Personnel should be guaranteed confidence during trouble times, ensuring sustenance. Financial and legal help post-problematic scenarios will make them confident.

\section{Information and Intelligence}

Details regarding the number, gender, leaders, mood, grievances, vehicles, direction, purpose, target, chances of a clash with a rival group, history of such type of crowd, and type of area should be available. Rumors should be countered effectively through different means. Law enforcement has its intelligence units but unfortunately, it is limited in terms of its capacity and function. Police should learn to read, analyze, store and process the intelligence to move forward as part of riot containment strategy (The Intelligence Process).

\section{Resource Support Cell}

A senior and experienced officer helped by experienced upper subordinates should plan and calculate human resources and equipment requirements. Human resources require the employment, training, facilities, compensations, legal benefits, and performance management merged and evaluated by the Commission to improve the overall working of the department (Report for the National Commission For Government Reforms, 2008). Additionally, the equipment inventory should be continuously updated. Keep track of supply and demand and, team to provide equipment and food.

Social media campaign before and after be launched for justification of police response. Protection of police and other sensitive/ vulnerable public and private property should be ensured. Backup of fresh personnel should be available. There should be a clear plan for prolonged public disorder. Every team should have designated team leaders with designated call signs and one communication link.

\section{Different Committees}

The task should be clearly defined to committees; prisoner escort, protection of police officers, documentation of all processes, lessons learned, and video making must be ensured.

\section{Verbal and Written abuse}

Verbal and written abuse may be anticipated. The purpose of this scheme is to demoralize law enforcement and causing them to take individual actions that may later be exploited a "police brutality" Use of force should be reasonable, necessary, and lawful. 
Police accountability is directly linked to the eradication of police complaints and thana culture that exists. This can be achieved if ill-treatment of protestors and detainees is avoided which otherwise leads to public dissatisfaction and police distrust. Police should steer clear of violations during the conflicts and use force only when required. Instances of mishandling, manipulation, and abuse can be prevented if the repressed institution's grievances are recognized ("This Crooked System" Police Abuse and Reform in Pakistan, 2016).

\section{Extra care to deal with accompanying groups}

Advocates, media, and others; Religious leaders, Politicians, ruling and opposition; Relatives of a person who died in custody and Labor unions are required to be dealt with extra care.

\section{Gauging potency}

The duration of stay, government's policy, standing in the society, interactions with the judiciary, relations with the police and LEAs, authority inherent in appointment, resources available, the loyalty of subordinates be gauged for appropriate response

\section{Calculation of assets}

The total strength of the law enforcement accounts for the assets in terms of personnel and officers. Currently, the police ratio to Pakistani citizens is one for every 304 persons. Consequently, the country should be prepared in terms of resource allocation, administrative measures, increase in training capacities and recruitment process to counter violent activities and mob-related scenarios (Abbas H. , Reforming Pakistan's Police and Law Enforcement Infrastructure, 2011).

Available support to the adversary, emotional appeal of their narrative, the significance of their holdup, number of the protesters, the capacity of the opposition to continue, all these should be taken care of. Trust of the followers in the leadership, the integrity of the leadership, and penetration of opposition in rank and file must unabatedly be calculated.

\section{Briefings and Debriefings}

Briefing/ debriefing sessions must be conducted every time the force goes out for mob control or as they return.

\section{Accountability Mechanism}

Successful procedures and mechanisms of accountability can significantly increase the prospective conditions of police. The department is expected to behave under legal obligations if there is senior management superintending their actions. This entails check and balance systems for smooth functioning of the department as well as improving the turbulent relationship between citizens and police ("This Crooked System" Police Abuse and 
Reform in Pakistan, 2016). Furthermore, the budget should be allotted explicitly to the police department, and the department should independently and judiciously expend the funds.

\section{Availability of Legal framework}

\section{Legal Protection}

Assurance of legal protection to police officers dealing with such situations against prosecution as provided under section 132(a) of Cr.PC is important. An Anti-violent crimes Act is required as a special law, as current PPC sections are not enough to deter savories. Such acts should define protest, categorize riots, violent episodes, and crime against police with appropriate penalization. It should give police powers to seize material detrimental to peace. Most of the officers are tangled and overtaken by the fear of being booked in FIR or facing an inquiry. Section 22-A and 22-B had inculcated fear in the police force. The organization should highlight and should get passed a law for legal protection to cover such situations. Interestingly, there are numerous legislations that facilitate impunity to the police, going back to the British administration. This includes the Criminal Procedure Code (1898), the Maintenance of Public Order Ordinance (1960), and the recently sanctioned Protection of Pakistan Act (2014), which actively participates in a legal framework providing a safety net to the police from accountability ("This Crooked System" Police Abuse and Reform in Pakistan, 2016).

\section{Implementation of Police Order 2002}

The Police Order 2002 was enacted on 14th August 2002, replacing the Police Act of 1861 in the four provinces. Interestingly the much-trumpeted law was never enforced in the capital of Pakistan. After the independence of Pakistan, there was a need for publicoriented and service-friendly legislation. The newly born country wanted the practice and execution of law and order in a peaceful environment guaranteeing security and liberty to the public. The responsibilities of the police were redefined to prevent crime and keep public order therefore, there was an emergence of new regulations, which included the public accountability of police (The Police Order 2002).

The police officers were to serve the community and tenure was a fixed period of three years (until removed on disciplinary grounds) which unfortunately has not been implemented (Abbas, 2012). A new concept of community policing was presented to assist the public instead of controlling them. Under this, the Public Safety and Police Complaint Commission was formulated to ensure a healthy and sociable relationship between the clients and protectors.

The Police Order 2002 also gave birth to the National Public Safety Commission programmed to initiate nationwide synchronization and execution of law-and-order standards for maximum dexterity among different departments and services. This plan was intended to bring independence and administrative power to the police department. Regardless, the proposal has not been implemented due to the clash of interests among different groups of authority. 
Police Order 2002 if employed, has the potential to establish a composed relationship between public and law-enforcement agencies. The removal of mistrust and misunderstandings that subsisted between them could be addressed to bridge a noticeable gap. The officers would be able to attend training workshops and programs to reshape their communication skills to respond to the needs of the public. These interpersonal and interactive skills can be extremely helpful in resolving conflicts and incongruities, particularly in large-scale demonstrations. Negotiations and diplomacy are vital features police need to be familiarized with for prompt solution of conflict resolution.

Governments have botched the proper implementation of this Act due to the existing conflicts. After 19 years, the Police Order 2002 has not been executed effectively by the provinces as well as the Federal government. Rather new laws contradicting original spirits and reversion have taken place in Sindh and Baluchistan, while KP has upgraded the Police Order 2002 (Kahlon, 2020). If multiple departments of executive and policing are integrated, then there are high chances of effective policing, with fair chances of an independent and non-aligned police department.

\section{Activation of Citizens-Police Liaison Committee (CPLC)}

A significant portion of the training period should be directed towards establishing a neutral and dependable relationship between citizens and police. The CPLC is a platform launched to minimize gaps between citizens and the police and is working well in Sindh. Established in 1989, the commission is responsible for providing funds and resources to different police stations, creating awareness and reliability-related plans between public and police stations. The whole concept of this plan was to improve the working relationship between communities and police stations (CPLC). This should be extended to other regions for streamlining relationships and adequately responding to adverse situations (Abbas $\mathrm{H}$. , Role of Pakistan Police in Counterinsurgency).

CPLC functions on the principles of shared interests, institutional formulation, and mutual goals allowing the police to cooperate with the organization. The understanding between police and CPLC is applause-worthy as the practical support and insights offered to the department is invaluable. This organization is considered highly successful as it has also provided a shield from extraneous intervention to the police which was a prevalent hindrance in their roles and duties (Masud, 2002).

\section{Engagement of NGOs; Shehri Citizens- Better Environment}

Another program such as Shehri Citizens for Better Environment is a Karachi-based nonprofit establishment that highlights police reform and better interaction among public groups. This organization is known to initiate effective programs and training workshops to encourage dialogue and negotiations between public and police departments.

In 2010 and 2019, this organization was known to arrange a workshop titled as Police Reform in Pakistan with Special Emphasis on Human Rights Training. Other projects such as the National Project for Participating Citizen - Police Interaction and Training for Improved Policing of Human Rights Violation discoursed reforms in policing by including hundreds of Police officers across Pakistan. The program inculcated elements of human 
rights awareness along with enhancing conflict resolution skills and negotiation power. It also launched a project titled as Pakistan Forum on Democratic Policing that strived to advocate policing at national and provincial levels in accordance with legal framework and principles of democracy (Projects - Pakistan Forum on Democratic Policing (PFDP), 2016).

\section{Training on Community Policing ; Rozan}

This nonprofit launched the Rabta police training sessions in collaboration with National Police Academy, National Police Bureau, Islamabad Police, and provincial police departments. This workshop was intended to develop the interpersonal and communication skills of inspectors and constables who are directly corresponding with the general public. Such programs and initiatives are helpful and valuable for the police personnel and its leadership structure to work on their weakened areas and reinforce conflict resolution skills. It helps them identify, evaluate, and analyze the situation through a critical lens (Sadiq, 2020).

The training assessment includes the existing Pakistani policies regarding human rights violation clauses, the religious perspective, and the religious standpoint on human rights infringement. Moreover, clauses concerning the security of minorities, women, and children within this society are also incorporated under these programs. These are the code modules that need to be explored and comprehended by the personnel to enhance their capacity and work within the policy structure to resolve conflict, riots, and imminent threats. Without these fundamental practices, the department would not be able to contain riot situations, resulting in volatility.

\section{Propositions}

Pakistan needs reform in the law enforcement infrastructure at the grassroots level. This need is gradually becoming evident, particularly in curtailing the ongoing ethnic, radical, religious protests that have created political disturbances across the country. The existing reforms in controlling crime and violence had a marginal impact on dealing with explosive situations mainly due to lack of coordination in the programs and uneven implementation among provinces. Legal reforms and skills development to handle pressure and predicaments as part of crisis management and training are extremely necessary to make such programs successful.

Besides, legal branches including the National Safety Public Commission must welcome experts from multiple fields and domains for diversity with no conflicts of interests. Fresh recruitments with state-of-the-art training intensity and absence of biases can only serve the purpose of police modernization in Pakistan (Abbass, 2020).

Furthermore, for reforms to materialize, the country must abandon and address internal gaps. From eradicating political employments to post, recruit, and promote on merit bases, the rule of law can be achieved. Corruption should be thoroughly dealt with along with investment in strengthening law enforcement capacity. Peace-oriented options should be formulated to control violence. Traditional and innovative reforms can help in improving the police infrastructure. The former involves elevating the personal status of police 
officers by providing them with generous salaries and extra facilities along with professional training and novel gadgets.

\section{Conclusion}

The police department needs a full-fledged intelligence system to remove uncertainties, internally cleanse the force, report and analyze the emerging threats. Until 2002, Pakistan had inadequate separate investigative branches as well as insufficient, under-resourced, under-mandated, and underutilized Police Special Branch to handle such challenges. Nevertheless, each police department should be thoroughly revolutionized for effective functioning and policing strategies (Petzschmann, 2010). Police are criticized for their incompetence when dealing with peaceful protesters, including students, teachers, nurses, but many times they have shown a degree of amazing courage as well. Pakistani junior police officers are acclaimed internationally during their tenure in UN peacekeeping operations. Moreover, specific institutions such as National Highways \& Motorway Police (NHMP) and Counter-Terrorism Departments (CTD) validate that there is a desire to reform.

The latest protest ended without a solitary admiring word for the police effort from the authority. Eleven police force members were abducted and held at Nawan Kot near Lahore, and 40 others were injured. Purportedly, in the parliament, prayers were said for the TLP protesters, without even highlighting or paying any homage to the police officers who got martyred. Nonetheless, the rule of law can only flourish if the culture of negotiation and settlement initiated by the police force, stakeholders, participants, and vested parties is acknowledged.

Police leadership must also speak out, plan and strategize to keep themselves abreast on all accounts to effectively respond, safeguarding their organization's work, force welfare in crisis, and its functional mandate of protecting citizens' life, property, and honor. Despite certain unfitting policies and practices, the police have been serving quite responsibly. Like other countries' institutions, many police officers fearlessly sacrificed their own lives to protect their citizens. Positive reinforcement of policing can be performed if it experiences the patronage, sponsorship, and admiration of citizens for which it must act professionally and reasonably on behalf of all citizens. 


\section{References}

Abbas, H. (2012). Stabilizing pakistan through police reform. Asia Society Washington:.

Abbass, M. (2020). How can police be reformed? Retrieved from https://www.thenews .com.pk/print/131776-How-can-police-be-reformed

Ahsen, S. B. (2018). Police service-challenges and reforms. Retrieved from https:// dailytimes.com.pk/306595/police-service-challenges-and-reforms/

Bhattacharya, S. (2016). Civil society in Pakistan: functioning and challenges. South Asian Journal of Multidisciplinary Studies, 3(3), 24-45.

Bilal, R. (2021). SC fixes for hearing petition seeking release of TLP chief Saad Rizvi. Retrieved from https://www.dawn.com/news/1634295/sc-fixes-for -hearing-petition-seeking-release-of-tlp-chief-saad-rizvi

Fasihuddin, S. (2012). Police education and training in Pakistan. Archivos de Criminología, Seguridad Privada y Criminalística(9), 9-10.

Haberfeld, M. R. (2006). Police leadership. Pearson Prentice Hall Upper Saddle River, NJ.

Hameed, Z. (2013). Extremism and Policing Challenges in Pakistan. Retrieved from https://www.hurights.or.jp/archives/focus/section2/2013/06/ extremism-and-policing-challenges-in-pakistan.html

Hashim, A. (2021). Protests continue across Pakistan over arrest of TLP leader. Retrieved from https://www.aljazeera.com/news/2021/4/13/protests-continue-across -pakistan-over-arrest-of-tlp-leader

Institute for Social Policy and Understanding. (2009). Police \& Law Enforcement Reform in Pakistan: Crucial for Counterinsurgency and Counterterrorism Success. Retrieved from http://www.ispu.org/files/PDFs/ISPU $\% 20 \% 20 \mathrm{Police} \% 20$ Reforms $\%$ 20in\%20Pakistan\%20Report.pdf

Kahlon, T. U. (2020). Policing the police: A democratic exiguity in Pakistan. ISSRA Papers.

Malik, S. M. (2009). Horizontal inequalities and violent conflict in Pakistan: Is there a link? Economic and Political Weekly, 21-24.

Mancini, F., Letouze, E. F., Meier, P., Vinck, P., Musila, G. M., Muggah, R., .. O'Reilly, M. (2013). New technology and the prevention of violence and conflict. International Peace Institute, UNDP, USAID (2013).

Manes, J. (2019). Secrecy \& evasion in police surveillance technology. Berkeley Tech. LJ, $34,503$.

Masud, M. O. (2002). Co-producing citizen security: the citizen-political liaison committee in Karachi.

Minhas, A. S., \& Shah, S. A. (2019). Police reforms: An Appraisal. ISSRA Papers.

Perito, R., \& Parvez, T. (2013). Empowering the Pakistan police. United States Institute of Peace.

Petzschmann, P. (2010). Pakistan's police between centralization and devolution. JSTOR.

Qadeer, M. (1997). The evolving structure of civil society and the state in Pakistan. The Pakistan development review, 743-762. 
Sadiq, D. E. (2020). Transforming police for 21st century: An evaluation of police training in Pakistan. Rozan.

Schaap, D. (2021). Police trust-building strategies. a socio-institutional, comparative approach. Policing and Society, 31(3), 304-320.

Siddiqi, M. U. A., Butt, K. M., \& Afzaal, M. (2014). Politicized policing in Pakistan: A constructivist study of problems of policing in Lahore. The Journal of Political Science, 32, 3.

Tanzeem, A. (2021). In Pakistan, Clashes Between Police, Islamists Reportedly Leave 2 Dead. Retrieved from https://www.voanews.com/south-central-asia/pakistan -clashes-between-police-islamists-reportedly-leave-2-dead

Waseem, Z. (2021). The Problems With Policing Pakistan. . Retrieved from https:// www . dawn. com/news/1622864/the-problems-with-policing-pakistan 